\title{
東日本大震災被災地に派遣された消防職員の ストレス症状と外傷後成長
}

\section{俞 善英 ${ }^{2}$ 韓国教育開発院 古村 健太郎 新潟大学 松井 豊 筑波大学 \\ 丸山 晋 ルーテル学院大学}

\begin{abstract}
The stress symptoms and posttraumatic growth of dispatched firefighters following the Great East Japan Earthquake
\end{abstract}

\begin{abstract}
Seonyoung Yoo (Korean Educational Development Institute), Kentaro Komura (Niigata University), Yutaka Matsui (University of Tsukuba), and Susumu Maruyama (Japan Lutheran College)
\end{abstract}

\begin{abstract}
This study investigated posttraumatic stress symptoms and posttraumatic growth among 534 fire fighters who were dispatched to the disaster area following the Great East Japan Earthquake. Specifically, we investigated the effect of acute stress symptoms and social support from peers and family on posttraumatic stress symptoms, depression, and posttraumatic growth one year after being dispatched. We found that dispatched fire fighters experienced posttraumatic growth as well as posttraumatic stress symptoms following disaster work. Moreover, social support from peers was positively associated with professional growth as a disaster worker, whereas social support from family positively associated with gratitude. These results imply that it is useful to take into consideration supporting the posttraumatic growth of fire fighters as an opportunity for professional growth with respect to stress management programs as well as relieving posttraumatic symptoms with early intervention.
\end{abstract}

Key words: fire fighters, stress management program, posttraumatic growth, social support, disaster worker.

The Japanese Journal of Psychology

2017, Vol. 87, No. 6, pp. 644-650

J-STAGE Advanced published date: November 10, 2016, doi.org/10.4992/jjpsy.87.15309

近年，消防職員の日常的現場活動によるストレス症 状や精神的健康に関する研究が増え, 年齢や災害時の 経験などが現場活動によるストレス症状と関連するこ とが明らかになっている（消防職員の現場活動に係る ストレス対策研究会, 2003)。さらに, 大規模災害現 場での救援活動による, 消防職員の外傷性ストレス症 状についても報告されている。例えば，兵庫県精神保 健協会こころのケアセンター（1999）では，阪神・淡

Correspondence concerning this article should be sent to: Seonyoung Yoo, Korean Educational Development Institute, Baumoe 1RD. 35, Umeondong, Seocho-gu, Seoul 06762, Korea. (E-mail: yoo1026516@ gmail.com)

本研究は, 総務省消防庁大規模災害時に係る惨事ストレス 対策研究会のデータによる。

デー夕使用許可を頂いた総務省消防庁および, 調查協力者 に記して感謝申し上げます。
路大震災に派遣された消防職員の PTSD ハイリスク率 は, 発災から 1 週間以降に派遣された後期派遣群で $4.2 \%$, 発災から 1 週間以内に派遣された早期派遣群 で $4.9 \%$ となっていた。

未曽有の災害となった東日本大震災においても, 被 災 3 県を除く全都道府県から約 7,577 隊 (約 28,620 人) の緊急消防援助隊が派遣され（総務省, 2011), 東日 本大震災の被災地へ派遣された消防職員の PTSD ハイ リスク率は発災3 力月後で $2.6 \%$ (大澤・加藤, 2011), 発災6力月後で $5.3 \%$ （烟中・俞・松井, 2011）と報告された。一方, 発災 5 力月後の PTSD 八 イリスク群に該当する人がいなかった報告（野島・岡 本・神山・和田・角田，2013）もある。

しかし， 9.11 テロ現場で活動した消防職員の発災か ら $2-3$ 年後の PTSD ハイリスク率が $12.2 \%$ であるこ と（Perrin et al., 2007）や, 消防職員の遅発性のスト レス反応（松井・畑中・丸山, 2011）を考慮すると, 
東日本大震災に緊急消防援助隊として派遣された消防 職員の活動が精神的健康に及ぼす長期的影響も検討す る必要がある。

また，外傷性出来事の経験は，必ずしもネガティブ な影響をもたらすわけではない。Tedeschi \& Calhoun （2004）は，外傷性出来事の経験によって生じる外傷 後成長を「危機的な出来事や困難な経験との精神的な もがき・戦いの結果生ずる，ポジティブな心理的変容」 と定義し, 外傷性出来事に関する侵入的熟考や意図的 熟考によって精神的健康の悪化や外傷後成長が促進さ れると主張した。Dekel, Ein-Dor, \& Solomon (2012)は, 外傷性出来事を経験した直後の外傷性ストレス反応が 10 年後の外傷性ストレス反応と外傷後成長を予測し, 外傷後成長には外傷性出来事による心理的苦痛が不可 欠なことを明らかにした。福岡（2008）は，ストレス フルな体験の種類によって，変化する自己概念の側面 （成長，否定，感謝）が異なり，自己概念の成長と感 謝が，家族や友人のサポート，体験の開示への周囲の ポジティブな反応と正の相関を示し，自己概念の否定 が, 体験の開示への周囲のネガティブな反応と正の相 関を示すことを明らかにした。

職業的救援者が救援活動中に体験した外傷性出来事 は，ネガティブな経験に留まるだけでなく，要救助者 や社会のために貢献する機会となった有意義な体験と しても意味づけられる。すなわち, 職業的救援者が救 援活動中に経験した外傷的出来事は，人間的成長のみ ならず，専門性を高める職務上の成長のきっかけとし ても捉えられる特有性を有している。

Paton（2006）は，職業的救援者における外傷後成 長を一般人のものと区別する必要性について，以下の 5 つの理由を挙げている。第一に, 職務上, 災害や事 故などの外傷性ストレッサーに繰り返し曝される。第 二に，人を助けたいという動機づけにより，職業的救 援者を選択している。第三に，外傷性ストレッサーに 曝される危険性の高い職種であるのにもかかわらず, 自発的にこの職業を選択している。第四に, 職務遂行 や組織的活動の中で外傷性出来事を経験している。第 五に, 動員, 救援活動, 回復, 再統合の段階で外傷的 出来事への関与度が進展し, 各段階で体験する外傷的 出来事の意味が異なる。

さらに，警察官を対象とした Paton \& Burke (2007) は, 1 つの外傷性出来事を経験した人では組織内での 労いなどのポジティブ経験と外傷後成長とは関連しな いが，2つ以上の外傷性出来事を経験した人では組織 内のポジティブ経験が多くなるほど外傷後成長も高く なることを明らかにした。すなわち，職務上，外傷性 ストレッサーに繰り返し曝される職業的救援者の外傷 後成長には，ストレス症状の緩和のみならず，労いの ような組織内でのポジティブ経験を促すなど，職業的 救援者の職務上の成長に焦点を当てた対策の必要性が
示唆された。

本邦の消防組織における惨事ストレス対策は，消防 職員の現場活動によるストレス症状の緩和に焦点が当 てられている。例えば, 総務省消防庁は 2003 年より「消 防庁緊急時メンタルサポートチーム」制度を開始し, 災害や事故に遭遇した各自治体の消防本部へメンタル ケアの専門家を派遣し, 精神的なケアや補助を行って いる。東京消防庁は，チームで救援活動を行う消防職 員において, 同僚職員のソーシャルサポートが精神的 健康の維持に重要な役割を果たしていることから, 消 防職員同士のソーシャルサポートを促すことに焦点を 当てた惨事ストレス対策を行っている（松井, 2005）。 しかし, 本邦では, 消防職員における外傷後成長に関 する知見が少ない。したがって, 消防職員の惨事ス卜 レス対策において外傷後成長を考慮した介入も必要と 考えられる。

以上より，消防職員における外傷性ストレス症状抒 よび外傷後成長の規定因を探索し, その特有性を明ら かにすることで, 消防職員に適した組織的介入の在り 方を提言できると考えられる。本論文ではその規定因 としてソーシャルサポートを取り上げる。

外傷性出来事の経験による外傷性ストレス症状の規 定因に関するメ夕分析（Brewin, Andrews, \& Valentine, 2000; Ozer, Best, Lipsey, \& Weiss, 2003）では, 外傷性 ストレス症状とソーシャルサポートとの間に負の関連 が示されている。同様に, 職業的救援者の外傷性ス卜 レス症状とソーシャルサポートの関連に関するメ夕分 析 (Prati \& Pietrantoni, 2010) でも, 同様の知見が得 られている。畑中・松井（2003）では，家族㧍よび消 防職員からのソーシャルサポートが消防職員の現場活 動での外傷性ストレス症状を低隇しており, 特に消防 職員からのソーシャルサポートの影響が強かった。ま た, 俞・松井 (2012) は, 消防職員が配偶者に職場内 の対人ストレスを開示することが精神的健康を促進す ることを示した。

外傷後成長に関するメ夕分析（Prati \& Pietrantoni, 2009）からも，ソーシャルサポートが外傷後成長に及 ぼすポジティブな影響が報告されている。 Linely \& Joseph（2006）は，災害救援者に打ける外傷後成長と ソーシャルサポートとの間に有意な関連がみられな かったと報告した。しかし, この研究は対象者数が 56 名に留まっている。さらに, ソーシャルサポート の測定は，サポート源を特定せず，受領されたサポー トとサポートに対する全般的満足度を測定しており， 外傷後成長の下位領域との関連が検討されていない限 界を有する。これらの問題を踏まえると, 消防職員が 現場活動による外傷後成長を経験する際に, 重要なサ ポート源である家族や同僚との関わりが外傷後成長の 下位領域にどのような影響を与えるかを検討する必要 がある。 
しかし，本邦では消防職員における外傷後成長に関 する検討が少ない。大規模災害時等に係る惨事ストレ 又対策研究会（2013）は, 被災地へ派遣された消防職 員が経験した外傷性ストレス症状の単純集計や, 救援 活動の成果，活動中の支えなどを報告しているが，そ れらの関連は検討していない。

以上より本研究は, 大規模災害時等に係る惨事又卜 レス対策研究会（2013）のデー夕を再解析し，東日本 大震災の被災地に派遣された消防職員が経験した救援 活動, 家族や同僚からのソーシャルサポートが 1 年半 後の外傷性ストレス症状や外傷後成長に及ぼす影響を 検討する。

\section{方 法}

調査対象者 東日本大震災の被災地に緊急消防援助 隊として派遣された消防司令以下の消防職員 640 名に 対し，2012 年 9 月に質問紙を配布し，返送された 538 名（男性 531 名, 女性 3 名, 不明 4 名）を分析対象と した3。なお，女性や性別不明の人が少ないため, 性別 を考慮した分析は行わない。

調查手続き 調査対象者の抽出は, 消防本部を職員 数で 7 層に層化し, 各層ごとに本部を抽出し, 本部の 職員数に応じて抽出数を決め, 等間隔抽出で対象者の 番号を決定した。この番号を，本部が所有する職員名 簿の順番に適用し，対象者を確定した。該当番号の職 員が司令長以上の階級の場合は，次の番号の職員を割 り当てた。抽出された職員には, 消防本部を通じて質 問紙を配布し，回答は個別，無記名で行われた。回答 した質問紙は郵送で回収した。質問紙の表紙には，調 查への回答の任意性や回答しないことで不利益を被ら ないことを明記した。

調查項目 （a）性別, 年齢 ${ }^{4}$, 婚姻状況, 過去の大規 模災害への派遣の有無を尋ねた。（b）派遣活動後の家 族と職場からのサポートを測定するため, 畑中他 （2011）より，派遣活動後の家族サポート 3 項目（「家 族に対して派遣活動での体験についてよく話した」, 「家族と, 他愛もない会話をよくした（している）」,「家 族があなたの努力や頑張りを認め, 労ってくれた」), 職場サポート 3 項目（「職場で, 派遣活動での体験に ついてよく話した」，「職場の上司や同僚と，他愛もな い会話をよくした（している）」,「職場の上司や同僚 があなたの努力や頑張りを認め, 労ってくれた」) に

\footnotetext{
調査対象者を消防司令以下とした理由は, 消防司令よりも 階級の高い管理職ではなく, 被災現場での活動を行う消防士の みを対象とするためである。

4 年齢は, 「1. 24 歳未満」,「2. 24 歳から 29 歳」,「3. 30 歳 から 34 歳」, 「4. 35 歳から 39 歳」,「5.40 歳から 44 歳」, 「6. 45 歳から 49 歳」,「7. 50 歳から 54 歳」, 88.55 歳以上」と尋ね, 分析に際し, 29 歳以下, 30 歳代, 40 歳代, 50 歳以上としてま とめた。
}

ついて，4 件法（1.あてはまらない一 4.あてはまる） で回答を求めた。（c）外傷後成長を測定するため, 福 岡（2008）のストレス体験を通じた心理的変化尺度の 感謝因子と成長因子を用いた。回答者の負担を考慮し, 各因子より福岡（2008）で因子負荷量の高かった 5 項 目ずつを抽出し，成長因子には職業的救援者の特有性 を反映した 3 項目（「活動を通して社会に貢献するこ とができた」，「自分の活動が誰かの役に立ったことを 実感した」,「消防職員としてのスキルや能力が向上し た」）を追加した。2 件法（1. 感じた, 2. 感じなかった) で回答を求め,「1. 感じた」と回答した個数を得点と した。（d）東日本大震災の外傷性ストレス症状を測定 するため, Weiss \& Marmer（1997）が作成した改訂版 出来事インパクト尺度 (Impact of Event Scale- Revised: 以下 IES-R とする) の日本語版 (Asukai et al., 2002) を用いた。 5 件法（0. 全くなし一 4 . 非常に）で回答を 求めた。(e)抑うつを測定するため, Kessler et al. (2002) が作成した K6 の日本語版（Furukawa et al., 2008）を 用いた。 5 件法 (0. 全くない一 4 . いつも) で回答を求 めた。（f）急性ストレス反応を測定するため，畑中 · 松井・丸山・小西・高塚 (2004) の PTSD 予防チェッ クリスト 19 項目と, 大規模被災地一派遣された消防 職員特有の心理的反応として独自に作成した 7 項目に ついて, 経験の有無を 2 件法（1.あった, 0.なかった) で求めた。なお, 質問紙には他の項目も含まれたが, 本研究では報告しない。

\section{結 果}

回答者の属性 回答者の年齢層は, 29 歳以下が 58 名 $(10.8 \%), 30$ 歳代が 211 名 $(39.2 \%), 40$ 歳代が 153 名 $(28.4 \%), 50$ 歳以上が 86 名 $(16.0 \%)$, 不明が 30 名 $(5.6 \%)$ であった。また, 既婚者は 467 名 (86.8\%) であり，過去に大規模災害に派遣されたことのある人 は345名（64.1\%）であった。

各変数の作成と記述統計量 急性ストレス反応の項 目について主成分分析を行い, .35 以上の主成分負荷 量を示した 15 項目を選択し, 再度主成分分析を行っ た（Table 1)。その結果，いずれの項目も.35以上の 負荷量を示した。 $\alpha$ 係数は.71 と十分な内的一貫性を 示していたため,「あった」の回答を加算し, 急性ス トレス反応の得点とした。外傷後成長の項目は, 成長 に関する 8 項目，感謝に関する 5 項目それぞれで主成 分分析を行った（Table 2)。感謝に関する 5 項目の中 で負荷量の高い項目が「他人を思いやる気持ちをもて るようになった」、「周りの人たちへの感謝の気持ちを もつようになった」であり,「生の意義」と解釈された。

各尺度の内的一貫性を確認するため， $\alpha$ 係数を算出 した結果（Table 3)，いずれも分析に耐えうる值であっ た。各尺度の年齢別の記述統計量を Table 3 に示す。 各変数の年齢差を検討した結果, 家族サポート, 職場 
Table 1

急性ストレス反応の主成分分析の結果

\begin{tabular}{|c|c|c|c|}
\hline No. & 項目 & 肯定率 & 負荷量 \\
\hline 6 & 隊長や同僚の指示が聞こえづらくなったり，音がよく聞こえなくなった & $1.7 \%$ & .55 \\
\hline 17 & 気が動転して方向や場所が分からなくなった & $0.4 \%$ & .54 \\
\hline 18 & 一時的に時間の感覚が麻痺（まひ）した & $7.2 \%$ & .51 \\
\hline 14 & 活動中, わけもなく怒りがこみあげてきた & $1.7 \%$ & .50 \\
\hline 3 & 強い動悸（どうき）がした & $4.1 \%$ & .46 \\
\hline 22 & 活動中に受けた衝撃が, 数時間しても目の前から消えなかった & $9.3 \%$ & .46 \\
\hline 26 & 涙がとまらなくなったり，涙もろくなったりした & $11.2 \%$ & .44 \\
\hline 15 & 現場が混乱し, 圧倒されるような威圧感を受けた & $4.5 \%$ & .44 \\
\hline 12 & 活動中，見た情景が現実のものと思えなかった & $42.5 \%$ & .44 \\
\hline 21 & 被災者や遺族に強く同情した & $40.0 \%$ & .40 \\
\hline 23 & 活動が実を結ばない結果に終わり, 絶望や落胆を味わった & $17.3 \%$ & .40 \\
\hline 24 & もっと役に立てないのかと自責の念にかられた & $44.4 \%$ & .38 \\
\hline 7 & 寒い日なのにおびただしい汗をかいた & $5.2 \%$ & .38 \\
\hline 19 & 目の前の問題にしか, 考えを集中することができなかった & $5.6 \%$ & .37 \\
\hline 1 & 胃がつかえたような感じがした & $4.5 \%$ & .35 \\
\hline & & & 2.96 \\
\hline
\end{tabular}

注）No. は項目番号を示している。

Table 2

外傷後成長の項目の肯定率と主成分分析の結果

\begin{tabular}{rlrr}
\hline No. & \multicolumn{1}{c}{ 項目 } & 肯定率 & 負荷量 \\
\hline & (人間的成長) & & \\
1 & 自分の活動が誰かの役に立ったことを実感した & $39.8 \%$ & .40 \\
2 & 活動を通して社会に貢献することができた & $45.2 \%$ & .41 \\
3 & 消防職員としてのスキルや能力が向上した & $38.1 \%$ & .56 \\
4 & 物事に取り組むときの忍耐強さが増した & $15.2 \%$ & .68 \\
5 & 困難な出来事にも立ち向かっていけると思うようになった & $17.8 \%$ & .70 \\
6 & 自分に自信がもてるようになった & $7.6 \%$ & .72 \\
7 & 精神的に強くなった & $19.1 \%$ & .61 \\
8 & 自分が一回り大きくなったような気がする & $16.7 \%$ & .61 \\
& (生の意義) & $41.4 \%$ & .55 \\
9 & 人間関係の大切さを実感するようになった & $27.1 \%$ & .55 \\
10 & 人々や物を, いて当たり前, あって当たり前だとは思わなくなった & $41.6 \%$ & .62 \\
11 & 生命の大切さを実感するようになった & $31.2 \%$ & .76 \\
12 & 周りの人たちへの感謝の気持ちをもつようになった & $22.7 \%$ \\
13 & 他人を思いやる気持ちをもてるようになった & .79 \\
\hline & & & 2.85 \\
\hline
\end{tabular}

注）主成分分析は, 項目 $1-8$ と項目 9-13 それぞれについて行っている。

サポート，IES-Rに年齢の主効果が見られ，40 歳代と 50 歳以上よりも 20 歳代と 30 歳代が家族からも職場 からもサポートを受けていると感じていた。また, 20 歳代と 40 歳代よりも50 歳以上が外傷性ストレス症状 を呈していた。
IES-R と K6 のハイリスク率 IES-R は 25 点以上 (Asukai et al., 2002) を，K6 は 10 点以上（Furukawa et al., 2008）をカットポイントとし，ハイリスク率を算 出した。その結果, ハイリスク群は, IES-Rで 19 名 $(3.6 \%), K 6$ で 5 名 $(0.9 \%)$ が該当した。また, 
Table 3

各変数の各年齢層ごとの平均と標準偏差ならびに平均值の差

\begin{tabular}{|c|c|c|c|c|c|c|c|c|c|c|c|c|c|c|}
\hline & \multicolumn{3}{|c|}{29 歳以下 } & \multicolumn{3}{|c|}{30 歳一 39 歳 } & \multicolumn{3}{|c|}{40 歳一 49 歳 } & \multicolumn{3}{|c|}{50 歳以上 } & \multirow{2}{*}{$F(d f)$} & \multirow{2}{*}{$\eta_{\mathrm{p}}^{2}$} \\
\hline & $n$ & $M$ & $S D$ & $n$ & $M$ & $S D$ & $n$ & $M$ & $S D$ & $n$ & $M$ & $S D$ & & \\
\hline $\begin{array}{l}\text { 家族サポート } \\
(\alpha=.69)\end{array}$ & 67 & $7.67^{\mathrm{a}}$ & 2.12 & 222 & $7.24^{\mathrm{a}}$ & 2.11 & 151 & $6.41^{\mathrm{b}}$ & 2.18 & 85 & $6.39^{\mathrm{b}}$ & 1.81 & $\begin{array}{l}9.51 * * * \\
(3,521)\end{array}$ & 0.05 \\
\hline $\begin{array}{l}\text { 職場サポート } \\
(\alpha=.77)\end{array}$ & 67 & $7.60^{\mathrm{a}}$ & 2.22 & 222 & $7.36^{\mathrm{a}}$ & 2.10 & 151 & $6.58^{\mathrm{b}}$ & 2.06 & 87 & $6.31^{\mathrm{b}}$ & 1.76 & $\begin{array}{l}9.54 * * * \\
(3,523)\end{array}$ & 0.05 \\
\hline $\begin{array}{l}\text { 成長 } \\
(\alpha=.73)\end{array}$ & 67 & 1.09 & 1.54 & 220 & 0.77 & 1.24 & 150 & 0.64 & 0.95 & 87 & 0.72 & 1.25 & $\begin{array}{c}1.84 \\
(3,520)\end{array}$ & 0.01 \\
\hline $\begin{array}{l}\text { 感謝 } \\
(\alpha=.67)\end{array}$ & 67 & 2.04 & 1.60 & 222 & 1.68 & 1.53 & 151 & 1.59 & 1.49 & 87 & 1.46 & 1.39 & $\begin{array}{c}2.10 \\
(3,520)\end{array}$ & 0.01 \\
\hline $\begin{array}{l}\text { IES-R } \\
(\alpha=.92)\end{array}$ & 67 & $4.00^{\mathrm{a}}$ & 4.81 & 219 & $4.34^{\mathrm{a}}$ & 7.35 & 149 & $4.85^{\mathrm{a}}$ & 5.38 & 82 & $7.88^{\mathrm{b}}$ & 9.41 & $\begin{array}{l}5.06 * * * \\
(3,513)\end{array}$ & 0.03 \\
\hline $\begin{array}{l}\mathrm{K}-6 \\
(\alpha=.88)\end{array}$ & 66 & 0.55 & 1.45 & 222 & 0.86 & 2.29 & 151 & 0.94 & 2.07 & 87 & 1.36 & 2.43 & $\begin{array}{c}1.90 \\
(3,522)\end{array}$ & 0.01 \\
\hline $\begin{array}{l}\text { 急性ストレス反応 } \\
(\alpha=.71)\end{array}$ & 66 & 3.36 & 2.21 & 220 & 3.24 & 2.45 & 147 & 3.33 & 2.69 & 83 & 3.87 & 3.01 & $\begin{array}{c}1.22 \\
(3,512)\end{array}$ & 0.01 \\
\hline
\end{tabular}

注）差がある条件に異なるアルファベットを記載した。

$* * * p<.001$

Table 4

重回帰分析（強制投入法）の結果

\begin{tabular}{|c|c|c|c|c|c|c|c|c|}
\hline \multirow[b]{2}{*}{ 説明変数 ～～～～～～～～～～} & \multicolumn{2}{|c|}{ 成長 a } & \multicolumn{2}{|c|}{ 感謝 b } & \multicolumn{2}{|c|}{ IES $-\mathrm{R}^{\mathrm{c}}$} & \multicolumn{2}{|c|}{$\mathrm{K} 6^{\mathrm{d}}$} \\
\hline & $\beta$ & $p$ & $\beta$ & $p$ & $\beta$ & $p$ & $\beta$ & $p$ \\
\hline 大規模災害への派遣経験 & .05 & .09 & .03 & .49 & -.08 & .06 & -.04 & .44 \\
\hline 婚姻状況 & -.12 & .01 & -.03 & .50 & .04 & .33 & .06 & .22 \\
\hline 年齢 & -.01 & .82 & -.07 & .15 & .14 & .00 & .06 & .22 \\
\hline 急性ストレス反応 & .19 & .00 & .34 & .00 & .49 & .00 & .30 & .00 \\
\hline 職場サポート & .23 & .00 & .06 & .27 & -.05 & .37 & -.05 & .40 \\
\hline 家族サポート & .02 & .77 & .15 & .01 & .02 & .77 & -.07 & .19 \\
\hline$R^{2}$ & .11 & .00 & .17 & .00 & .26 & .00 & .11 & .00 \\
\hline
\end{tabular}

${ }^{\mathrm{a}} n=475,{ }^{\mathrm{b}} n=478,{ }^{\mathrm{c}} n=473,{ }^{\mathrm{d}} n=479$

IES-R と K6 のどちらもハイリスク群であった人は 1 名 $(0.2 \%)$ であった。

IES-R, K6, 成長, 感謝の規定因 成長, 感謝, IES-R，K6 の規定因を検討するため，これらの変数を 目的変数, 大規模災害への派遣経験, 婚姻状況, 年齢, 職場サポート，家族サポート，急性ストレス反応を説 明変数とした重回帰分析 (強制投入法) を行った (Table 4)。この際, 大規模災害への派遣経験（1=あり，0= なし）と婚姻状況（1=既婚， $0=$ 未婚）はダミー変 数化した。

分析の結果, 成長は婚姻状況と負の関連, 急性ス卜 レス反応および職場サポートと正の関連を示した。感 謝は急性ストレス反応，家族サポートと正の関連を示 した。IES-R は年龃および急性ストレス反応と正の関 連を示した。K6 は急性ストレス反応と正の関連を示
した。

\section{考察}

被災地での救援活動から 1 年半後の精神的健康状態 について検討した結果, IES-Rによる PTSDハイリス ク群は 3.6\%, K6 によるハイリスク群は $0.9 \%$ であり, IES-R と K6 の両方ともハイリスク群に該当した人は $0.2 \%$ であった。年齢別にみると，50 歳以上の消防職 員が 20 歳代と 40 歳代より PTSD を呈しており, 消防 職員の現場活動に係るストレス対策研究会（2003）と 整合していた。すなわち，PTSDハイリスク群の比率 は発災6力月（畑中他，2011）よりは低いものの，派 遣から 1 年半後においても被災地での救援活動による PTSD を経験していることが明らかになった。

また，被災地での救援活動による急性ストレス反応 
は, 派遣から 1 年半後の外傷性ストレス症状, 抑うつ と正の関連を示した（Table 4)。これらの結果は PTSD の規定因として外傷周辺的感情的反応および解 離症状を挙げる知見と整合し（Ozer et al., 2003）, 消 防職員のメンタルヘルス対策への事案発生直後の介入 の重要性を示している。

一方，被災地での救援活動による急性ストレス反応 は外傷後成長とも正の関連を示し，外傷性出来事の経 験によるストレス反応が外傷後成長を予測した Dekel et al.（2012）の知見と整合した。さらに，同僚や家族 からのソーシャルサポートも外傷後成長と正の相関を 示したが, そのパターンは異なっていた。具体的には, 職場で, 派遣活動の体験について話すことや, 他愛の ない話，労いが「活動を通して社会に貢献することが できた」などの成長と正の関連を示し，家族に派遣活 動の体験について話すことや, 他愛のない話, 労いが 「生命の大切さを実感するようになった」などの感謝 と正の関連を示した。すなわち，消防職員の外傷後成 長は, 事案経験後の他者との関わりによって外傷後成 長の生じる領域が異なっていた。外傷後成長研究の文 脈で捉えれば，同僚からのソーシャルサポートは職業 的救援者としての成長につながり，家族からのソー シャルサポートは感謝へつながることが明らかになっ た。この結果は，大学生において家族および友人のサ ポートや体験の開示に対するポジティブな反応が成 長・感謝と正の相関を示した福岡（2008）とは異なっ ており, 外傷性ストレッサーに繰り返し曝されながら も組織内のポジティブ経験を通して職務上の成長を経 験できる職業的救援者の特有性（Paton, 2006）を示し ていると考えられる。なお，婚姻状況と成長は負の関 連を示しており，結婚している人よりも独身の人が成 長を感じていた。この結果が示された理由について, 本研究からは明確な結論が出せないため, 今後の検討 が必要である。

以上の結果より，職業的救援者が救援活動中に経験 した外傷的出来事は，専門性を高める職務上の成長の きっかけとなる可能性があり, その際には組織の役割 が重要であると主張したPaton（2006）および Paton \& Burke（2007）の知見をより詳細に実証できたと考 えられる。従来の対策のように早期介入を通して消防 職員が現場活動によって経験しうる外傷性ストレス症 状の軽減の重要性に加え，救援活動中に経験した外傷 的出来事を職務上の成長のきっかけとして捉えられる 自衛隊員や警察官などの職業的救援者の特有性 （Paton, 2006）を考慮した外傷後成長を促進するため の対策も立てる必要がある。具体的には，外傷後成長 に焦点を当てた啓発活動や心理支援を通して外傷後ス トレス症状の経験を外傷後成長に活かせる環境を整え ることが重要である。

本研究は縦断研究ではなく，急性ストレス反応を回
顧法で測定している限界を有する。したがって，縦断 研究や他の職業的救援者集団との比較を通して, 消防 職員の外傷後成長におけるソーシャルサポートの影響 やその特有性についてより綿密に検討する必要があ る。

\section{引用文献}

Asukai, N., Kato, H., Kawamura, N., Kim, Y., Yamamoto, K., Kishimoto, J., \& Nishizono, M. A. (2002). Reliability and validity of the Japanese-language version of the Impact of Event Scale-Revised (IES-R-J). Journal of Nervous and Mental Disease, 190, 175182.

Brewin, C. R., Andrews, B., \& Valentine, J. D. (2000). Meta-analysis of risk factors for posttraumatic stress disorder in trauma-exposed adults. Journal of Consulting and Clinical Psychology, 68, 748-766.

大規模災害時等に係る惨事ストレス対策研究会 (2013)．大規模災害時等に係る惨事ストレス対策 研究会報告書 総務省消防庁

Dekel, S., Ein-Dor, T., \& Solomon, Z. (2012). Posttraumatic growth and posttraumatic distress: A longitudinal study. Psychological Trauma: Theory, Research, Practice, and Policy, 4, 94-101.

福岡 欣治（2008）。ストレス体験に伴う相互作用と自 己概念の肯定的 / 否定的変化一一実行されたサ ポートの役割に注目した探索的検討——日本社 会心理学会第 49 回大会発表論文集, 230-231.

Furukawa, T. A., Kawakami, N., Saitoh, M., Ono, Y., Nakane, Y., Nakamura, Y., ... Kikkawa, T. (2008). The performance of the Japanese version of the K6 and K10 in the World Mental Health Survey Japan. International Journal of Methods in Psychiatric Research, 17, 152-158.

畑中 美穂・松井豊 (2003)。抑制的会話態度およびソー シャルサポートが消防職員の精神的健康に及ぼす 影響 日本心理学会第 67 回大会論文集, 172 .

畑中 美穂 - 松井 豊 · 丸山 晋 - 小西 聖子 - 高塚 雄介 (2004). 日本の消防職員における外傷性ストレス トラウマティック・ストレス, 2,67-75.

畑中 美穂 - 俞 善英 ·松井 豊 (2011). 東日本大震災 の被災地派遣消防職員における惨事ストレス— 派遣先での体験内容とストレス反応の検討第 10 回日本トラウマティック・ストレス学会抄 録集, 44 .

兵庫県精神保健協会こころのケアセンター (1999). 非常事態ストレスと災害救援者の健康状態に関す る調查研究報告書 兵庫県精神保健協会こころの ケアセンター

Kessler, R. C., Andrews, G., Colpe, L. J., Hiripi, E., Mroczek, D. K., Normand, S. L., ... Zaslavsky, A. M. (2002). Short screening scales to monitor population prevalences and trends in non-specific psychological distress. Psychological Medicine, 32, 959-976.

Linely, P. A., \& Joseph, S. (2006). The positive and nega- 
tive effects of disaster work: A preliminary investigation. Journal of Loss and Trauma, 11, 229-245.

松井豊 (2005)。惨事ストレスへのケア おうふう

松井 豊・畑中 美穂・丸山晋 (2011). 消防職員にお ける遅発性の惨事ストレスの分析 対人社会心理 学研究, $11,43-50$.

野島 真美 · 岡本 博照 - 神山 麻由子 - 和田 貴子 · 角田 透（2013）。東日本大震災に派遣された消防官の 惨事ストレスとメンタルヘルスについての横断研 究 杏林医会誌, 44,13-23.

大澤智子 ・加藤寛 (2011)。被災地派遣職員が被る惨 事ストレスの影響——的トラウマ研究——兵 庫県こころのケアセンター研究紀要, 7, 25-32.

Ozer, E. J., Best, S. R., Lipsey, T. L., \& Weiss, D. S. (2003). Predictors of posttraumatic stress disorder and symptoms in adults: A meta-analysis. Psychological Bulletin, 129, 52-73.

Paton, D. (2006). Posttraumatic growth in disaster and emergency work. In L. G. Calhoun \& R. G. Tedeschi (Eds.), Handbook of posttraumatic growth: Research and practice (pp. 225-247). Mahwah, NJ: Lawrence Erlbaum Associates Publishers.

Paton, D., \& Burke, K. (2007). Personal and organizational predictors of posttraumatic adaptation and growth in police officers. Australasian Journal of Disaster and Trauma Studies, 1, 1-12.

Perrin, M. A., DiGrande, L., Wheeler, K., Thorpe, L., Farfel, M., \& Brackbill, R. (2007). Differences in PTSD prevalence and associated rescue and recovery workers. American Journal of Psychiatry, 164, 1385-
1394.

Prati, G., \& Pietrantoni, L. (2009). Optimism, social support, and coping strategies as factors contributing to posttraumatic growth: A meta-analysis. Journal of Loss and Trauma: International Perspectives on Stress \& Coping, 14, 364-388.

Prati, G., \& Pietrantoni, L. (2010). The relation of perceived and received social support to mental health among first responders: A meta-analytic review. Journal of Community Psychology, 38, 403-417.

総務省 (2011). 緊急消防援助隊の活動終了 総務省 消防庁 Retrieved from http://www.fdma.go.jp/neuter/ topics/houdou/h23/2306/230606_1houdou/01 houdoushiryou.pdf (2015 年 7 月 8 日)

消防職員の現場活動に係るストレス対策研究会 (2003)．消防職員の惨事ストレスの実態と対策の あり方について 地方公務員安全衛生推進協会

Tedeschi, R. G., \& Calhoun, L. G. (2004). Posttraumatic growth: Conceptual foundations and empirical evidence. Psychological Inquiry, 15, 1-18.

Weiss, D. S., \& Marmar, C. R. (1997). The Impact of Event Scale-Revised. In J. P. Wilson \& T. M. Keane (Eds.), Assessing psychological trauma and PTSD: A practitioner's handbook (pp. 399-411). New York: Guilford Press.

俞 善英・松井 豊 (2012)。配偶者に対する消防職員の ストレス開示抑制態度が精神的健康へ及ぼす影響 心理学研究, 83, 440-449.

2015. 7.8 受稿, 2016.7.16 受理—— 